\title{
Emerging Prospective of Floriculture Industry: Drying of Ornamental Plants and their Parts
}

\author{
Shailza*, Shalini Jhanji and H.S. Grewal \\ Department of Floriculture and Landscaping, Punjab Agricultural University, \\ Ludhiana, Punjab, India \\ *Corresponding author
}

\begin{abstract}
A B S T R A C T
Dry flowers are economically important because fresh flowers are short lived and will retain only for few days or week while dry material will last indefinitely may be up to

\section{Keywords}

Dry flowers, Drying techniques,

Preservation

Article Info

Accepted:

10 June 2018

Available Online:

10 July 2018 months or years. In this modern era, dry flowers and other plant parts such as pods, fruits, fruiting shoots, preserved leaves etc. has become the choice of many people in their lifestyles for interior decorations, bouquets, wall decors and in many other dry flower products. Dry flower industry is a major segment of floriculture industry and contributes $71 \%$ of total floriculture export. The demand of dry flowers is increasing day by day thus offering ample of job opportunities for thousands of unemployed man and women especially housewives. There are many techniques of drying such as air drying, press drying, embedded drying, microwave drying, preservation etc. which are used for drying of different flowers such as Zinnia, Carnation, Sweet William, Stock, Pansy, Freesia, Chrysanthemum, Marigold, Rose and foliage such as Ferns, Aspidistra, Eucalyptus etc. In this review the scattered information on flower drying and their value addition is being compiled which would be useful for further studies and would also helpful in entrepreneurship development in unemployed youths as well as in housewives and rural women for earning money through this creative occupation.
\end{abstract}

\section{Introduction}

Flowers are wonderful creation of nature regarded as a symbol of love, beauty and a paradigm of life. Besides their aesthetic value, flowers play important role in improving the environment in addition to their economical and medicinal properties. Flowers are synonyms of delight and blissfulness due to their power to make people happy and cheerful (Anon., 2015). Flowers are available in varied colours used to express human feelings. Even our day begins with worship of God with flowers as people believe that flowers can also please the spirits of their ancestors. Some flowers like Jasmine, tuberose, rose etc. are used by women and their extracts are integral part of many cosmetics. Flowers are used in many forms as loose flower, cut flower and dry flower from time immemorial for decorating homes due to their fragrance and welcome the guests at home. Flowers are known for their insecticidal and medicinal properties as 'Pyrethrin', a well 
known insecticide is extracted from Chrysanthemum flowers, and leaves of Periwinkle are used to cure diabetes and high blood pressure.

Fresh flower production under open and protected conditions is predominant in floriculture industry. The fresh flowers, though exquisite in their beauty, are expensive, short lived, sensitive to temperature and are available only during a particular season. Their freshness and beauty is lost due to various biochemical changes and microbial activities, thus, can be retained only for few days even by using the best techniques of post-harvest management (Datta, 1999). The shelf life of flowers could be prolonged only to an extent of $40 \%$ even when the best flower preservatives or chemicals were used (Ranjan and Misra, 2002). The vase life of Narcissus cv. Texas could be extended from 12 to 18 days with treatment of $\mathrm{CaCl}_{2}(50 \mathrm{ppm})$ + STS (50 ppm) (Siddique et al., 2012). The post- harvest life of cut chrysanthemum flowers was increased from 19.16 days to 26.83 days with $4 \%$ sucrose (Srivastava et al., 2015).

In the recent years, the demand of flowers and foliages all over the world is increasing for decoration with ecofriendly things, but their availability throughout year at different places is one of the limiting factor. Further, decoration with fresh flowers and foliages is also expensive, time consuming and short lived. The dried or dehydrated flowers or plant parts are natural, comparatively inexpensive and have everlasting value with year around availability (Safeena et al., 2006). By using dehydration technique the charm of ornamental flowers could be enjoyed for several years without disturbing their colour and form (Bhutani, 1990; Datta, 1999; Ranjan and Misra, 2002). The flower drying techniques involve reducing moisture content of flowers to a point at which biochemical changes are minimized while maintaining cell structure, pigment level and flower shape (Singh et al., 2003).

Preserving plant material in dry form has been considered as an art of hundreds of years and fragrant dried herbs were encased with mummified bodies in Egyptian pyramids. It has been a form of artistic expression that was very popular in Victorian ages. Dry flower arrangements have been popular in Europe for centuries, and Americans used dried flowers to brighten their homes, especially during the dark winter months as early as 1700 (Brown et al., 2013). Earlier, Herbalists used dry flowers obtained through pressing for the preparation of herbarium (Lawrence, 1969). Now, this process is moving from an art to a highly interdisciplinary science and has become a major economic activity on a global scale (Verma et al., 2012). The dried ornamental products offer a wide range of qualities like novelty, longevity, aesthetic properties, flexibility and year round availability (Joycee, 1998). Recently, dry flowers have established their tremendous potentiality as a substitute of fresh flowers for interior decoration.

\section{Dry flower industry}

Dry flower industry in India is more than 40 years old mainly due to its high export value. Dry flowers were introduced initially by the British in Calcutta due to its nearness to northeast and eastern regions where exotic and diverse blooms were available in nature (Bhattacharjee and De, 2003). Dry flowers are essential export items both in national and international markets. Indian export of flowers is composed of $71 \%$ dry flowers exported mainly to USA, Japan, Australia, Russia and Europe (De et al., 2016). Exporting companies at Kolkata in West Bengal, Tuticorin in Tamil Nadu, Mumbai in Maharashtra and Hyderabad in Andhra Pradesh are earning 10-15 times higher returns than domestic markets (Verma 
et al., 2012). Dry flower market has grown exponentially as consumers have become "eco-conscious" and choose dry flowers as the environment friendly and biodegradable alternative to fresh flowers (Datta and Roy, 2011). Different decorative floral craft items like cards, floral segments, wall hangings, landscapes, calendars, potpourris etc. could be made by using these dried flowers or foliages (Bhutani, 1990). This industry is labourintensive and generate ample job opportunities to thousands of unemployed men and women. Thus, there is large potential to develop the dry flower industry to provide employment mainly to house wives and rural women.

In India, non-availability of information on dry flowers has been a major constraint in the promotion of dry flower industry (Datta and Roy, 2011). Being largely focused on the quality of attractive flowers, living plants and plant parts, floriculturists generally pay little attention to dry and preserved flowers and other attractive plant parts. Therefore, these products remain overlooked and under-rated even due to their considerable economic importance for their aesthetic contribution which is largely discounted. In comparison to post harvest floriculture, relatively little publicly funded research and development have been undertaken on drying and preserving of ornamental materials. The privately funded research and development work has been sustained, but findings are usually kept secret to protect investments (Joycee, 1998). As a result, dry flower component of floriculture industry has been ill defined in terms of techniques, products and organizations and, there is an urgent need of enhanced professionalism and various research programmes in the trade of these products. The different steps involved from harvesting to marketing of dry flowers, foliage and plant parts have been reviewed in this chapter to develop understanding for expansion of dry flower industry.

Stage of harvesting
The quality of dry flowers is influenced mainly by the harvest stage of flowers and should be kept in mind before performing any drying technique. The appropriate stage of flower to be harvested is when they just began to mature or at a fully open stage although it varies according to the species and the form of desired flower. Flowers could be harvested either at bud stage or later stages until their colour has not faded. The delay in harvesting time (2- 3 days) result in folding of petals over one another which causes their shattering (Bhattacharjee and De, 2003). Smith (1993) reported that flowers like Strawflower, Globe Amaranth, Salvia, Chrysanthemum etc. should be harvested at bud stage or partially open stage as these flowers continue to open while drying. Safeena et al (2006) reported that rose flowers harvested at half bloom stage give superior quality of dry roses and minimum time for drying with better colour retention due to colour stability at this stage. Sangama (2004) reported that fully opened stage of Helichrysum flowers took lesser time for drying than those harvested at tight bud and half open stage. This might be due to the reason that flowers loose moisture with delay in harvesting time (Kofranek and Halevy, 1972). In embedding method of drying, half bloom stage flowers took less time for drying than harvested at bud stage because the petals were loosely arranged in half bloom stage of flowers which accommodated the desiccants between petals for faster dehydration. Flowers or plant parts selected at any stage for drying may be sprayed with Dithane Z-78 or Neem based pesticide $(0.5 \%)$ for disinfection (De et al., 2016).

\section{Selection of colour}

Various plant pigments are responsible for the flower colours due reflection of light. Chlorophyll is the primary pigment present in plants responsible for green colour. Pink, red, blue etc. colours are due to the presence of 
anthocyanin pigment and yellow coloured flowers are due to presence of carotenoids. The pigments behave differently in the drying process which denatures the chemical structure and loss of colour (Yu et al., 2006).

The colour of fresh flowers at harvesting is an important factor contributing for good aesthetic quality and market value of dry flowers, however, the colour fades during drying process resulting in loss of their aesthetic and ornamental value. Degradation of pigments during drying results in change of colour of flowers into brown which are not suitable for future use (Jean and Lesley, 1982). The flowers, therefore, should be selected on the basis of colour for drying. Pertuit (2002) found that blue and yellow coloured flowers retained their colour when air dried but pink flowers were faded in some plants. White et al (2002) reported that the red flowers turned to dark purple or bluish, pure blue acquired lavender or purplish colour, pink colour changed to red while magenta turned to lavender but yellow and orange colours were usually well preserved and also intensified well after drying. Usually, the flower colour fades in the natural drying process, but loss of colour was not observed in embedding method.

Champox (1999) reported silica gel as the best medium for getting excellent dry flowers with colour and shape retention. Batra (2015) studied the behaviour of colour change in some dehydrated ornamental plants and observed that Echium, Delphinium and Nymphea had same colour before drying i.e. bluish violet which was also retained in Centaneura and Viola and slightly changed in Echium. This could be explained as most of the red and blue coloured flowers have anthocyanin pigment, which is dissolved in the vacuoles of the epidermal cells of petals. Thus, the behaviour of flower colour after dehydration not only depends on category of pigment but also on internal or ultra structural factors. Therefore, flower colour as well as method of drying should be taken into consideration for getting excellent quality of dry flowers.

\section{Methods of drying or dehydration}

Several methods are practised for drying or dehydration of different flowers or its plant parts. In these methods, removal of moisture is done artificially either by using desiccants or controlled temperature, humidity and airflow. The principle involved in all the methods or techniques is common in which the plant material is exposed to a vapour pressure deficit (v.p.d. = v.p.source - v.p.sink), which induces water vapour to move by transpiration or evaporation from the plant material (source) into the surrounding environment (sink).

The flux of water vapour $(\mathrm{J})$ is proportional to the vapour pressure deficit; i.e. $\mathrm{J}=\mathrm{k} \mathrm{x}$ (v.p.d.); where $\mathrm{k}$ is a constant and depend upon the water vapour transfer properties of the particular product (Joycee, 1998). Following methods of drying or dehydration are commonly used for flowers or plant parts:

\section{Natural drying}

This is the easiest and oldest method of drying used for leaves, flowers, pods etc. In this method, the flowers or plant parts are allowed to dry on the plant itself and collected when they are completely dried.

Raj and Gupta (2003) reported that the important naturally dried plant parts such as beautiful fruiting shoots of Aegle marmelos, Bambusa spp., Cassia fistula, Caesapinia sepiaria, Pinus roxburghii, Sapindus mukrossii etc. and seeds of Abrus precatorius/ Aesculus indica, Sapium sebiferum etc. were identified in the outer Himalayan regions. 


\section{Air drying}

It is an inexpensive method of drying also referred as 'Upside Down' or 'Hang and Dry' method of drying (Verma et al., 2012). Flowers of good quality at slightly immature stage should be selected in this method and foliage is removed from the flowers. The flowers in bunches are then tied inverted either in a warm dark area or in sunlight. Drying in direct sunlight should be avoided as it causes discolouration. The flowers could also be spread over blotting sheets or newspapers and kept in dark or in sun for drying (Datta, 1997). Air drying requires a warm, clean, dark and well ventilated area with low humidity (Raghupathy et al., 2000). Sell (1993) reported that rooms with 75 per cent or more relative humidity such as basements should be avoided because it resulted in mould growth which spoiled the flowers.

This method takes 1-2 weeks for drying depending upon the moisture content, temperature and humidity. Brown et al (2013) reported that fleshier the flowers or foliage, the more time it will take to dry. The stage of harvest is also important for getting superior quality of dry flower in this method. Flowers like strawflower, Globe Amaranth, Salvia, Chrysanthemum etc. should be picked at bud stage or partially opened as they continue to open while drying (Smith 1993). Pertuit (2002) found that flowers dried by this method are extremely stiff, therefore; flowers with crisp texture eg. Acroclinium, Anaphalis, Helichrysum, Delphinium, Oregano, Rumex, etc. are suitable for drying. Flower colour should also be kept in mind before selecting the flowers for air drying. Blue and yellow coloured flowers retained their colour after air drying but pink colour fades away (Dilta et al., 2011). The main drawback of this method of drying is weather dependence and low quality of the product. The petals may shrink and sometimes droop down resulting in the loss of decorative value of the product (Verma et al., 2012). Plant materials suitable for air drying are Baby's Breath, Bachelor's Button, Globe Amaranth, Statice, Straw flower, Oregano, Larkspur, Cocks Comb, Golden Rain Tree, Bougainvellia, Bristly Foxtail, Eulalia grass, Fountain grass, Spike grass, Northern Sea Oats etc.

\section{Water drying}

Water drying is another simple and inexpensive method of flower drying or dehydration. In this method the flowers or foliages are initially placed in a few centimetres of water and then water is allowed to evaporate. The container and flowers should be kept in a dry, warm and dark location (Verma et al., 2012). This method takes 6-7 days for drying depending upon the water content in plant material and water taken in container. Plant materials suitable for water drying are Hydrangea, Cornflower, Baby's Breath, Celosia, Bells-of-Ireland etc.

\section{Press drying}

This is one of the common, easy and inexpensive method of drying. In this method, specimen is kept in folds of newspaper, blotting paper or old notebooks etc, and then a heavy object is placed on the top. Sheets could also be put one above the other and corrugated boards of the same size are placed in between the folded sheets to allow the water vapour to escape (Bhutani, 1990). Time required for pressing varies with type of flowers and water content of tissue; however, it should be completed within four weeks (Sell, 1993). This drying time could be reduced if flowers folded in the sheets are put in oven at an appropriate temperature (Datta, 1997). Kher and Bhutani (1979) found that press drying in oven at $35-39^{\circ} \mathrm{C}$ for 48 hours was optimum for Pansy, whereas, the leaves of Silver Oak, 
Thuja, Adiantum, Nephrolepis and flowers of Hibiscus, Haemotoxylon, Calliandra, Marigold and Cassia biflora required 24 hours for drying. Raj (2006) reported that for quicker drying, a herbarium press should be kept in hot air oven at $45^{\circ} \mathrm{C}$ for $12-24$ hours depending upon the moisture in the flowers and foliage. Press dried samples are used in card making, wall hangings, batches, stationary candles etc. The main disadvantage with press drying is that the shapes of the flowers cannot be maintained as it becomes flattened, because the fresh material after pressing within the iron or wooden frame tends to stick to the paper (Prasad et al., 1997) but, the original colour of pressed sample is maintained (Datta, 1997). Plant materials suitable for pressing are Candytuft, Chrysanthemum, Pansy, Rose, Daisy, Phlox, Statice, Zinnia, Ferns, Silver Oak, Blue Gulmohar, Thuja, Cockscomb etc.

\section{Hot air oven drying}

Temperature plays an important role in drying of flowers and other plant parts and specimens are kept at controlled temperature conditions for a specified period of time in hot air oven (Bhattacharjee and De, 2003). Verma et al (2012) reported that oven drying is the best method to have superior or better quality product. Mayak and Halevy (1980) reported that at higher temperature the rate of transpiration was comparatively much higher. Diffusion pressure deficit of air increases with increase in temperature that stimulates diffusion and vaporization of internal moisture leading to high moisture loss.

Drying in hot air oven or microwave takes less time as compared to the other methods such as air drying or water drying; however, the duration and drying temperature varies with plant size, structure, moisture content and stage of harvesting of the material. Half opened flowers or flowers at bud stage were suitable for drying in hot air oven while fully opened flowers were not suitable as their petals loose elasticity and peel off easily on drying (Verma et al., 2012). The drying temperature also varied from species to species and plant to plant. Kher and Bhutani (1979) reported that $35-39^{\circ} \mathrm{C}$ temperature was optimum for Bougainvillea (48 hours), Pompon Dahlias and Narcissus (72 hours). The temperature of $40-44^{\circ} \mathrm{C}$ temperature was found optimum for Aerva javanica, Callistephus chinensis, Euphorbia leucocephala, Delphinium ajacis, Mina lobata, Rose buds and Zinnia linearis (48 hours), Tagetes patula, medium and large Rose flowers (72 hours), Gladiolus and very large Rose flowers (96 hours), whereas, 45$49^{\circ} \mathrm{C}$ temperature was optimum for Helipterum roseum, small flowered perennial Chrysanthemum, Candytuft, Dombeya, Gerbera, Gomphrena, Helichrysum and Statice (48 hours), Tagetes erecta (96 hours) and for water lily (120 hours). Safeena et al. (2006) studied the response of drying in hot air oven at different temperatures $\left(30,40\right.$ and $\left.50^{\circ} \mathrm{C}\right)$ on the quality of rose and found that drying of Dutch rose flowers at $40^{\circ} \mathrm{C}$ by embedding in silica gel gave the best results for colour, texture and appearance. It was found that the flowers dried in hot air oven by embedding in silica gel took more time for drying than those which were not embedded in silica gel because hot air required time to heat the desiccants before desiccating the flowers, resulting in increased time for complete removal of moisture in the embedded flowers. Sharma et al (2016) performed an experiment on hot air oven drying of chincherinchee (Ornithogalum thyrsoides Jacq.) at different temperatures $\left(50,55\right.$ and $\left.60^{\circ} \mathrm{C}\right)$ for different durations (24, 48 and 72 hours) by using four drying media for embedding of flowers viz., silica gel, borax, sand + silica gel $(50: 50 \mathrm{v} / \mathrm{v})$ and sand + borax $(50: 50 \mathrm{v} / \mathrm{v})$. It was found that the flowers embedded in silica gel kept at $50^{\circ} \mathrm{C}$ for 24 hours showed the maximum score 
for quality parameters and minimum score was observed in flowers dried at $60^{\circ} \mathrm{C}$ for 24 hours in borax.

Singh et al (2004) reported that higher the temperature, faster was the dehydration as well as degradation of pigments viz; chlorophylls, carotenes, xanthophylls. The anthocyanin content of flowers increased with increase in temperature which resulted in darkening of flower petals (Nirmala et al., 2011). The darkening of flower could be due to increase in temperature which caused liberation of moisture outside and also increased the concentration of the pigments following water loss. The most important advantage of oven drying method is that the process of drying is comparatively faster than air-, water- and embedding- drying but if the temperature of hot air oven is more than $50^{\circ} \mathrm{C}$ than the flowers shrink. Plant materials suitable for hot air oven drying are Paper flower, Gerbera, Dahlia, Chrysanthemum, China Aster, Statice, Bougainvilleas, Marigold, Silver fern, Golden fern, Adiatum etc.

\section{Microwave drying}

This is the quickest method of drying which generates little amount of heat also. It is based on the principle of liberating moisture by agitating water molecules in the organic substances with the help of electronically produced microwaves (Bhattacharjee and De, 2003). White et al (2002) reported that microwave oven dried flowers looked fresh and more colourful than obtained by any other method. Drying in microwave takes only 5-10 minutes for drying while in hot air oven flowers dries in 6-24 hours. The major advantage of rapid drying was improved retention of natural flower colour (Bhutani, 1990). Plant sap contains dissolved sugars, acids, phenols and many other similar compounds and in this process when water content in the sap of the shoot declines, the concentration of these solutes increases which initiates the likelihood of being undergoing degradative chemical reactions and many of these chemical reactions either degrade the natural pigments or lead to browning (Biswas and Dhua, 2010). Rothemberger (2000) advocated a cup of water in the microwave before starting to prevent excessive drying. Containers with flowers after taking out from microwave should be kept for a particular period of time at room temperature so that the moisture evaporates and the plant material is fully dried. This is called 'setting time' which varies from s0pecies to species (Verma et al., 2012). Aravinda and Jayanthi (2004) standardized the drying techniques like microwave drying, oven drying and sun drying for chrysanthemum (Button type local) flowers and found that microwave drying with silica gel gave the best results for retaining shape of flowers while oven drying with white sand was found the best for colour and overall acceptability. Dhatt et al (2007) dried rose buds in microwave oven for 3,4 and 5 minutes, respectively, and found that rose buds dried for 4 min exhibited good colour and good shape retention. Biswas and Dhua (2010) performed an experiment on microwave oven drying of cut Carnation varieties viz., Kristina and Cano. These were harvested at fully opened stage and then subjected to drying treatments in microwave oven (1200 watt) after embedding them in silica gel (desiccant) for 2 to 4 minutes. The quality of dried flowers deteriorated more with increase in the drying duration and the lowest drying duration of 2 minutes showed the best results in both varieties with respect to appearance, colour, shape and sizes of dried flower as compared to drying duration of 3 or 4 minutes.

Microwave oven drying is not suitable for all flowers. It is the best for flowers with many petals such as Marigold, Rose, Carnation and 
Zinnia. Thomler (1997) reported that flowers with cluster of florets such as Golden Rod, Gypsophilla and Corn flower etc. are more suitable for microwave drying while flowers with thin, delicate petals or those with hairy and sticky surfaces are not much suitable for drying in microwave. Verma et al (2012) reported that flowers with thick petals or high water content such as Magnolia, Hyacinth and orchids do not dry well in microwave. Plant materials suitable for microwave drying are Snapdragon, China Aster, Chrysanthemum, Larkspur, Golden Rod, Gypsophilla, Acroclinum, Ixora, Candytuft etc.

\section{Embedded drying}

Embedded drying is one of the method of flower dehydration useful for delicate flowers with high moisture content that shatter or misshapen when air dried. This method of drying is usually preferred over air or oven drying as it reduces the problem of petal shrinkage. In embedded drying, the water content of the flower is completely absorbed by the surrounding desiccant material during desiccation (Safeena and Patil, 2013). The desiccants support the flowers/ foliage from all around and thus, maintains original shape, colour and size of flowers for a long time (Raj, 2006). The commonly used desiccants are silica gel, borax, corn meal, etc., which remove water from the flowers more rapidly than air-drying besides retaining the flowers in their natural form. Singh et al (2004) found that media influenced both flower colour as well as texture. Drying with sand provided smooth petal texture, silica gel provided slight rough and borax provided more rough texture of flowers.

Containers such as earthen pots, dark trays, microwave safe open containers, candy tins, plastic containers, large mouth jars or any other with a tight fitting lid are being used for embedding. These containers should be deep enough to accommodate the plant material without disturbing its shape and form.

\section{Drying of flowers by using desiccants}

Desiccant is any material which removes the moisture quickly from the ornamental flowers or plant parts embedded without reacting with water vapour released during drying. The ideal size of desiccant should be $0.02-0.2 \mathrm{~mm}$ or 20 200 mesh (Raj, 2014). The following desiccants can be used for drying of flowers.

\section{Sand}

Drying with sand is one of the least expensive method of dehydration of flowers. Fine white sand found on the seashore (river sand) can be used for embedding because of its easy handling and availability (Datta, 2001). Kher and Bhutani (1979) described the properties of sand with respect to drying of flowers. The fine sand does not react with the water vapour released during the process of drying like silica gel and borax. It allows the water vapour to escape into the air freely thereby causing minimum loss in the size of flowers which is otherwise maximum in silica gel embedded flowers. Sand from the river or beach should be washed and baked in the oven until dry (Verma et al., 2012). Organic materials and salts should be strained out before use. Since sand is heavier, it takes a longer time for drying than the other desiccants. It usually takes 4 days to 2 weeks for drying, however, for rapid drying two parts of borax should be added to one part of sand, and than one tablespoon of salt to each quart is added. Orduno and Baltazar (1995) studied the effects of river or sea sand in combination with borax on drying of rose, carnation and gerbera. Rose and carnation dried well in river sand containing a high proportion of borax within 15-20 days period, whereas, sea sand with a low proportion of borax for 10-15 days resulted in better dried gerberas. 
Although sand is cheap and results better quality of dried flowers but, it takes longer time for drying due to its heavy weight which sometimes destroy the specimens or tends to flatten flowers unless used very carefully. So, sand is not preferred as a desiccant as compared to silica gel, borax, cornmeal, however, in case sand needs to be used, it should be used in combination with cornmeal or borax for embedding purpose.

\section{Borax}

Borax is the least expensive and best suited method for dehydration of delicate flowers which are less stiff than those preserved with "Hang and Dry method" (Verma et al., 2012). Bhattacharjee and De (2003) suggested that borax and alum being light in weight could also be used for dehydration of flowers in combination with sand or corn meal for embedding. Sujatha et al (2001) reported that borax crystals and sand in the ratio of 1:1 was the best combination for drying as it helped to regain brightness and colour. Trinklein (2006) reported that sand is heavier in weight and tends to flatten flowers unless used very carefully. Thus, borax in combination with cornmeal is the best mixture for embedding because cornmeal is lightweight and has fewer tendencies to flatten flowers and also makes flower boxes easier to handle. Plant materials suitable for drying in borax are Rose, Aster, Carnation, Marigold, Dahlia, Larkspur, Geranium, Zinnia, Chrysanthemum and Delphinium are more suitable for drying in borax (Smith, 1993). Datta (1997) reported that due to hygroscopic nature of borax it could cause bleaching, brittleness and sometimes burn the flower petals if embedded for a long time.

\section{Silica gel}

Silica gel is the best desiccant for getting excellent quality of dry flowers that retain colour and shape (Champoux, 1999; Verma et al., 2012) since, it does not cause bleaching or brittleness to flower petals even if embedded for a long time. Silica gel is composed of a network of interconnecting microscopic pores which attract and hold moisture by a phenomenon known as physical adsorption and capillary condensation, thus, acting as a dehydrating agent (Safeena et al., 2006) which is actually sugar in granular shape. It is called gel because it is a xerogel of silicic acid (Orduno and Baltazar, 1995). Silica gel (60120 mesh) is the best absorbent for removing moisture from flowers and it prevents shrinkage of flowers and degradation of colouring pigments that could take place when petal tissues are exposed to high temperature (Safeena et al., 2006). Singh et al. (2003) reported that due to the strong hygroscopic nature of silica gel and borax, drying was much faster in comparison to sand which lead to rapid removal of moisture from flowers. Sandhu (2002) recommended silica gel embedding as the most appropriate method for proper colour retention of Helichrysum and Statice. Kher and Bhutani (1979) reported that flowers embedded in silica gel remained intact throughout the drying process and maintained the original shape and appearance. Dhatt et al. (2007) studied the methods of drying of rose buds and found that silica gel embedding of rose buds had the best quality with respect to colour and shape. Anemone, Baby's breath, Bachelor's button, Cosmos, Gladiolus, Delphinium, Larkspur, Salvia, Sunflower etc. are suitable for drying using silica gel. Silica gel, blue when dry and turn pink after absorbing moisture, is quite expensive and can be reused by warming up in oven till the crystals turn blue in colour (Paul and Shylla, 2002).

\section{Freeze drying}

Freeze drying is one of the most advanced drying technique being used worldwide. It was 
introduced in the year 1813 by William Hyde Wollaston to the Royal Society in London (Verma et al., 2012). Freeze drying relies on the principle of sublimation, whereby ice under conditions of partial vacuum $(<4.58$ Torr) and low temperature $\left(<0^{\circ} \mathrm{C}\right)$ evaporates on heating without going through a liquid phase. The absence of liquid water during the dehydration process means that undesirable chemical reactions will not occur. Thus, the dried material retains colour and even fragrance (Dubois and Joyce, 2005). In this process, the flowers are placed in a refrigerated chamber and temperature is lowered below freezing. A vacuum is then created in the chamber, causing the moisture in the flowers to sublimate, or change from solid to gaseous form. The water vapour is collected in a separate chamber and the dried flowers are allowed to slowly warm to room temperature (Trinklein 2006).

The full drying cycle takes 5-9 days for drying. Bhattacharjee and De (2003) found several cultivars of carnation which were successfully 'Cryo' dried and remained naturalistic in appearance after being placed at $-20^{\circ} \mathrm{C}$ for 12 hours and then placed in freeze drier for 7 days. The main advantage of freeze-drying is that the original texture, structure and highly volatile components including aroma could be retained in freezedried products. Sohn et al (2003) studied the effect of freeze drying on Rosa hybrida cvs Tineke, Golden Gate, Saphir, Roulette, Rote Rose for 14 days on their shape and colour. They observed shrinkage in all freeze dried flowers but the colour of Tineke and Golden Gate remained closest to fresh rose while the colour of Rote Rose was changed.

The freeze-dried flowers still remain valuable and justify the substantial cost of freezedrying. The shape, size, and colour of dried flowers remained almost similar to those of fresh ones (Chen et al., 2000). Freeze dried flowers are used to make open baskets, open wreaths, open bouquets, etc. Bridal bouquets could be preserved by this technique of drying without any damage. The disadvantages of freeze-drying are its high cost and precise processing techniques. The initial cost of equipment investment, electrical energy consumption and maintenance are relatively higher than those for other drying techniques, however, the quality of the finished floral product is almost doubled. Freeze dried flowers are fragile and care should be taken while handling and their storage. The cartons containing dry flowers should be strong enough to protect them during transportation.

\section{Solar cooker}

Flowers can be directly embedded in the container of solar cooker and dried under the sun. The time of exposure varies according to day temperature. The solar cooker can also be operated by using electricity and it could be most suitable technique for rural women as they can cook food in a solar cooker and utilize it for dehydration for rest of the time (Katagi et al., 2014).

\section{Preservation with glycerine}

Ornamental plant parts are generally preserved by treatment with 'humectants'. 'Humectants' are hygroscopic chemicals, which help to maintain the suppleness of dried plant material by attracting water vapour from the surrounding atmosphere. Thus, the preserved plant material is less brittle than dried material, making it less prone to shattering and mechanical damage (Raj, 2014). The difference in preservation and other methods of drying is that the treated parts are actually preserved and not completely dried. Different humectants are used for preserving plant parts such as glycerine, polyethylene glycol etc. 


\section{Glycerine}

It is one of the best dehydrating agent as it is an osmotic reagent (Harten, 2002) which retains flexibility, shape and texture of foliage (White et al., 2007). It preserves foliage by replacing the natural moisture present in the material with a substance that maintains the foliage form, texture and sometimes the colour. De et al (2016) reported that foliage could be preserved by immersing in 33\% glycerol solution. Semant et al (1993) observed that 1 part of glycerine mixed with 2 parts of hot water was the ideal mixture for twigs of 26 different plant species for dehydration. Sell (1993) used glycerine: hot water (1:2) to preserve Magnolia stems and found that mature leaves responded well to glycerine treatment as they translocated the solution readily to stems. Vishnupriya and Jawaharlal (2014) performed an experiment on glycerinization of foliages for making of dry flower products and found that full dip method of glycerine (50\%) improved all the quality parameters for Podocarpus and uptake method of glycerine (10\%) improved all the quality parameters for Leather Leaf Fern, Baby Eucalyptus and Silver Dollar. Glycerine also served as a good source for the growth of micro-organisms and antibiotic is necessary to prevent microbial growth in the dried specimens (Prasad et al. 1997).

The duration of treatment varied from 2 to 6 weeks depending upon the texture and the size of the leaves and branches. Plant materials are not allowed to stand in the solution for longer time as it results in glycerine bleeding. Sweating also occurs when there is sudden drop in the humidity from a high level. Thus, there is drastic reduction in the water holding capacity of dehydrating agent which then releases free water. This water cannot evaporate quickly enough and collects as droplets on the surface of the plant material where it provides an ideal environment for bacterial or fungal growth. Keeping the level of humectants in the plant tissues as low as practicable and by storing glycerine foliage at low humidity, sweating can be minimized (Verma et al., 2012). Plant materials suitable for glycerinization are Anthurium, Aspidistra, Beech, Juniper, Lemon, Maples, Statice, Periwinkle, Oaks, Magnolia, and Eucalyptus etc.

\section{Value addition}

\section{Bleaching and sulphuring}

The attractive plant material which is inherently coloured by unwanted pigments or discoloured due to oxidative browning, can be bleached or sulphured for its use in various floral arrangements for their value addition. Bleaching involves chemical process that can change the ability of colour bodies to absorb light by changing their degree of saturation. Both oxidative and reductive bleaches can be used on the plant material. Oxidative bleaches such as chlorates, hypochlorites and peroxides or peroxy compounds tend to break down the coloured compounds while reductive bleaches such as barohydrides and sodium sulphide tend to modify them into colourless compounds. Bleaching i.e. discolouration also allows the use of dyes for colouring of plant material.

Sulphuring is done to prevent enzymatic colour change. Sulphur dioxide acts to bleach coloured plant material, and below a certain concentration, to fix colours in some flowers. Colour fixation is associated with acidification of the tissues. Sulphuring is done by burning sublimed sulphur powder or by injecting sulphur dioxide gas (1-3 percent) into a sealed chamber. The plant material is usually treated with sulphur dioxide overnight prior to ventilation of the chamber and subsequent completion of the drying process (Verma et al., 2012). 


\section{Colouring}

The decorative value of dry flowers could be increased by dyeing (colouring). Colouring of dried flowers not only preserves their naturalness but can also become vital for marketing of the product.

Dyes are usually applied by immersion of fresh, dried or bleached ornamental plant parts. Before immersion waxy cuticle layer is removed from dried plant material with Sodium Hydroxide $(\mathrm{NaOH})$. Surfactants are added to improve contact between dye bath solution and plant material. In addition to dyeing, the plant material could also be coloured by painting (Bhattacharjee and De 2003).

\section{Packaging, handling and storage}

Packaging for delicate dried plant materials should be done properly and manually during transportation and distribution by creating awareness of the product characteristics. It is always advisable to purchase a superior grade or standard cartons or boxes for packaging. Dried plant material should be protected from moisture throughout the marketing channel by placing a small quantity of silica gel at the bottom to absorb moisture. Different containers like glass desiccators, tin boxes, cartons wrapped with plastic sheets or wax paper and herbarium vasculums fitted with cork sheet are used for storage of dried ornamental plant material.

Dry material should be protected from direct sunlight or high light intensity especially from incandescent lamps, atmospheric humidity, wind and dust. Thus, dried plant parts should be covered with plastic or transparent glass and stored in dust free area. The cartons or boxes used for storage should be cleaned from time to time (Datta, 1997; Bhattacharjee and De, 2003; Nair et al., 2014).

\section{Insect, pests and diseases}

Insect pests can afflict all types of dehydrated plant parts. Book lice, silver fish and mice are the common pests infesting dried plant material. These could be controlled by insecticides applied in the solid pest strips (Dichlorvos), liquid (synthetic pyrethroids, ethyl parathion $0.01 \%$ ) or gas (methyl bromide, phenyl tablets). The most common genera of fungi, namely Aspergillus, Penicillium and Rhizopus infest dried plant material. Therefore, plant material before collection should be treated with Dithane M45 (0.2\%). Sulphur burning or sulphur dioxide fumigation also reduced these fungi during storage (Raj, 2006).

In conclusion, dried flowers and plant parts are cheaper, eco-friendly, long lasting, biodegradable and easily available and, therefore, possess a great potential in floriculture industry throughout the world especially in the hilly regions of India. Great variation of wild plant material available widely also strengthen the establishment of dry flower industry. Intensive care should be taken from harvesting till marketing of the plants and its dry parts. Different techniques have been developed by which dried products retain their fresh look, appearance and quality. Keeping in view the great scope in dry flower industry, there is an immediate need to strengthen its market, financial assistance through government agencies and training for entrepreneurship development especially for women empowerment in India and through export of dry flowers to different countries of world.

\section{References}

Anon. 2015. Importance of flowers in our lives. [Online] Available: https://encyclopidia.wordpress.com/20 15/03/23/importance-of-flowers-in- 
our-lives/.

Aravinda, K., and Jayanthi, R. 2004. Standardization of drying techniques for chrysanthemum (Dendranthema grandiflora Tzvelev cv. 'Button Type Local') flowers. J. Orn. Hort. 7(3-4): 370-375.

Batra, A. 2015. To study the behaviour of colour change in some dehydrated ornamental flowers. Int. J. Latest Res. Sci. Tech. 4(4): 141-144.

Bhattacharjee, S.K., and De, L.C. 2003. Dried flowers and plant parts, In: Advanced commercial floriculture. Avishkar Publishers, Jaipur, pp. 162-273.

Bhutani, J.C. 1990. Capturing nature, a way with flower "Everlastings". Ind. Hort. 34(4): 15-19.

Biswas, C., and Dhua, R. S. 2010. Microwave oven drying of cut carnation. J. Orn. Hort. 13(1): 45-49.

Brown, S.P., White, P., Tija, B., and Sheehan, M.R. 2013. Drying and preserving plant materials for decorative uses. Available:

https://edis.ifas.ufl.edu/pdffiles/EP/EP 00400.pdf/ .

Champoux, J. 1999. Tips and home remedies. Available: http://www.kaepsmlin.com/tips.html/.

Chen, W., Gast, K.L.B., and Smithey, S. 2000. The effects of different freezedrying processes on the moisture content, colour and physical strength of roses and carnations. Scientia Hort. 84(3/4): 321-332.

Datta, S. K. 1997. Dehydration of flowers and foliage and floral craft. NBRI Bulletin No. 3, EBIS, NBRI Lucknow. pp. 20.

Datta, S.K. 1999. Dehydrated flowers and foliage and floral crafts, in: Bose, T.K., Maitti, R.G., Dua, R.S., Das, P. (Eds), Floriculture and landscaping. Naya Prokash, Kolkata, India. Pp. 696-703.

Datta, S.K. 2001. Dehydration of flowers and foliage in floral crafts. Floriculture Today. 5: 11-12.

Datta, S.K., and Roy, S. 2011. Employment generation using dehydration technology for drying flowers and foliage and floral craft. Sci. Cult. 77(1-2): 58-61.

De, L.C., Rai, W., Sumanthapa, and Singh, D.R. 2016. Drying technologies of commercial flowers- an overview. Int. J. Res. Appl. Nat. Social Sci. 4(3): $111-120$

Dhatt, K.K., Singh, K., and Kumar, R. 2007. Studies on methods of dehydration of rose buds. J. Orn. Hort., 10(4): 264267

Dilta, B.S., Sharma, B.P., Baweja, H.S., and Kashyap, B. 2011. Flower drying techniques - A review. Int. J. Farm Sci. 1(2): 1-16.

Dubois, P., and Joyce, D., 1989. Drying cut flowers and foliage. Farm note No. 10/89, Western Australian Department of Agriculture. Pp. 3.

Harten, C., 2002. Preserving flowers. Available:

http://www.thegardener.btinternet.co.u $\mathrm{k} /$ preserving.html/.

Jean, L., and Lesley, G. 1982. The complete guide to drying and preserving flowers. Webb and Bower Ltd, England.

Joycee, D.C. 1998. Dried and preserved ornamental plant material: not new but often overlooked and underrated. Acta Hort. 454: 133-145.

Katagi, A., Ishwaree, R.M., and Hosur S. 2014. Flower Dehydration: A Profitable Business for Rural People. Popular Kheti. 2(2): 56-60.

Kher, M.A., and Bhutani, J.C. 1979. Dehydration of flowers and foliage. Extension Bulletin No 2, NBRI, Lucknow. Pp. 20.

Kofranek, A.M., and Halevy, A.H. 1972. Condition for opening cut 
chrysanthemum flower buds. J. Amer. Soc. Hort. Sci. 92(5): 578-584.

Lawrence, H.M.G. 1969. Taxonomy of vascular plants. Oxford and IBH Publishing Co. Inc, Calcutta. Pp. 777.

Mayak, S., and Halevy, A.H. 1980. Flower senescence, In: Thimann, K.V. (Eds.), Senescence in Plants, CRC Press, Boca Raton. Pp. 132.

Misra, P., Banerji, B.K., and Dwivedi, A.K. 2009. Dehydration of Zinnia in an oven for value addition through embedding technique. J. Orn. Hort. 12(3): 222-224.

Nair, B., Singh, K.P., and Sengupta, S.K. 2014. Flower Dehydration- A Novel Technique in Indian Floriculture Industry. Int. J. Adv. Appl. Sci. 2: 5560.

Nirmala, A., Chanadrasekhar R., Padma, M., and Kumar, M.R. 2011. Effect of different media and microwave oven drying on production of quality dry flowers of Carnation cv. Master. J. Res. ANGRAU. 40(1): 1-5.

Orduno, C.A., and Baltazar, B. 1995. Effect of different mixtures of sand and borax on the drying of three flower species. Serie Hort. 1(3): 93-97.

Paul, D., and Shylla, B. 2002. The art of flower drying, in: Mishra, R.L., Mishra, S. (Eds.), Floriculture research trends in India, Indian society of ornamental horticulture, New Delhi. Pp. 41-46.

Pertuit, A. 2002. Drying flowers. Available: http://hgic.clemson.edu/factsheets/hgi c 1151.htm/.

Prasad, J.J.K., Pal, P.K., and Voleti, S.R. 1997. Drying of flowers: an upcoming industry. Floriculture Today. Pp. 2023.

Raghupathy, R., Amuthan, G. and Kailappan, R. 2000. Dried flowers: Significance. Kisan World. 28: 39.

Raj, D. 2006. Drying of attractive plant parts and flowers, In: Advances in ornamental horticulture, Pointer Publishers, Jaipur. 5: 189-198.

Raj, D. 2014. Dried Ornamentals, In: Floriculture at a glance, Kalyani publishers, third ed. Pp. 106-116.

Raj, D., and Gupta, P. 2005. Standardizing dehydration technology for ornamental herbaceous plant from outer Himalayas. J. Orn. Hort. 8(1): 53-55.

Ranjan, J.K., and Misra, S. 2002. Dried flowers: a way to enjoy their beauty for a long period. Indian Hort. 46(4): 32-33.

Rothenberger, R.R. 2000. Drying flowers and foliage for arrangements. Available: http://www.muextension.missoure.edu /explor/agguides/hort/go6540.html/.

Safeena, S.A., and Patil, V.S. 2013. Effect of hot air oven and microwave oven drying on production of quality dry flowers of Dutch roses. J. Agric. Sci. 5: 179-189.

Safeena, S.A., Patil, V.S., and Naik, B.H. 2006. Standardization of stage of harvest for better quality of dry flowers of rose. J. Orn. Hort. 9(3): 224-226.

Sandhu, A. 2002. Studies on the dehydration of winter annuals. Master's Thesis, Department of Floriculture and Landscaping, Punjab Agricultural University, Ludhiana, Punjab, India.

Sangama, 2004. Dehydration and product diversification of Helichrysum flowers. J. Orn. Hort. 7(3-4): 376-380.

Sell, R. 1993. Dried and fresh cut flowers. NDSU Extension Service, North Dakote State University of Agriculture and Applied Science, USA.

Semant, P.K.S., Dash, D.K., Barik L.R., and Dhar, A.N. 1993. Effect of glycerine on preservation of foliage of some ornamental plants. Orissa J. Hort. 21: 73-75. 
Sharma, G., Kashyap, B., Sharma, B.P., Gupta Y.C., and Gupta, R. 2016. Studies on hot air oven drying of chincherinchee (Ornithogalum Thyrsoides Jacq.) J. Hill Agric. 7: 5255.

Siddique, M.A.A., Masoodi, N.H., Masoodi, M., and Iqbal, S. 2012. Studies on the effect of pulsing on vase life of Narcissus cv Texas under different holding solutions. J Res. Dev. 12: 3-8.

Singh, A., Dhaduk, B.K., and Shah, R.R. 2002. Effect of different drying conditions and temperatures on chloroplast and vacuolar pigment content in Zinnia flowers. J. Orn. Hort. 5(2): 66.

Singh, A., Dhaduk, B.K., and Shah, R.R. 2003. Effect of dehydration on post harvest life and quality of zinnia flowers. J. Orn. Hort. 6(2): 141-142.

Singh, A., Dhaduk, B.K., and Shah, R.R. 2004. Effect of different temperature and embedding media on flower dehydration of zinnia (Zinnia linearis Benth.). Indian J. Hort. 61(3): 249252.

Smith, A. 2000. 'Even better than the real thing'. Flower business International, September 25-28.

Smith, R.C. 1993. Methods of preserving flowers. NDSU Extension Service, North Dakote State University of Agriculture and Applied Science, USA.

Sohn, K.H., Kwon, H., and Kim, E.Y. 2003. Effects of drying methods on shape and colour of Rosa hybrida. Korean J.
Hort. Sci. Tech. 21(2): 136-140.

Srivastava, R., Sharma, G., and Chand, S. 2015. Post-harvest life of cut chrysanthemum cultivars in relation to chemicals, wrapping material and storage conditions. J. Hort. 2: 123.

Sujatha, A.N., Damodaran, T., and Shiva, K.N. 2001. Dry flower industry in Andamans. Kissan World. 28: 28.

Thomler, J. 1997. Drying flowers and leaves. http://www.nectar.com.au./jascraig/cra $\mathrm{ft} /$ drieddf.htm/.

Trinklein, D. 2006. Drying flowers and foliage for arrangements. Available: http://extension.missouri.edu/publicati ons/Display Pub/

Verma, A.K., Dhiman, M.R., Kumar, D., and Gupta, A. 2012. Preserving flowers and plant parts, In: Post harvest technology for commercial floriculture. New India Publishing Agency New Delhi, India. Pp. 143171.

Vishnupriya, K., and Jawaharlal, M. 2014. Glycerinization of foliages for dry flower products making. Int. Q. J. Life Sci. 9(2): 507-511.

White, P., Tijia, B., and Sheehan, M. R. 2002. Drying and preserving plant materials. University of Florida Co-operative Extension Service. Pp. 53.

$\mathrm{Yu}$, O., Matsuno, M. and Subramanian, S. 2006. Flavonoid compounds in flowers: Genetic and biochemistry. Floriculture, ornamental and biotechnology, Global Science Book, UK. 1: 282-292.

\section{How to cite this article:}

Shailza, Shalini Jhanji and Grewal, H.S. 2018. Emerging Prospective of Floriculture Industry: Drying of Ornamental Plants and their Parts. Int.J.Curr.Microbiol.App.Sci. 7(07): 1619-1633. doi: https://doi.org/10.20546/ijcmas.2018.707.190 